\title{
Possibility of using by-products of the steelmaking industry for removing lead from aqueous solutions ${ }^{(*)}$
}

\author{
M.I. Martín*, F.A. López ${ }^{* *}$, F.J. Alguacil ${ }^{* *}$
}

\begin{abstract}
A study is made of the use of two steelmaking industry by-products (rolling mill scale and blast furnace sludge) as adsorbent materials for removing $\mathrm{Pb}^{2+}$ ions from aqueous solutions. The adsorption of $\mathrm{Pb}^{2+}$ on these materials has been studied by the determination of adsorption isotherms. Several variables that affect the process (contact time, initial lead ion concentration and temperature) were evaluated. The adsorption processes are analysed using the Langmuir theory. Desorption processes for the metal from loaded by-products were also studied under different experimental conditions. This paper shows that these industrial residues are effective adsorbents for lead ions in aqueous solutions within the range of working concentrations.
\end{abstract}

\section{Posibilidad de usar subproductos de la industria del acero para eliminar plomo de soluciones acuosas}

\begin{abstract}
Resumen
Se estudia el uso de dos subproductos de la industria del acero (cascarilla de laminación y lodo de horno alto) como materiales adsorbentes para eliminar iones $\mathrm{Pb}^{2+}$ de soluciones acuosas. La adsorción de $\mathrm{Pb}^{2+}$ sobre estos materiales se ha estudiado determinando las isotermas de adsorción. Se evaluaron diferentes variables que afectan al proceso (tiempo de contacto, concentración inicial de iones plomo y temperatura). Los procesos de adsorción se estudian usando la teoría de Langmuir. Los procesos de desorción de los metales también se estudiaron bajo diferentes condiciones experimentales. Este trabajo muestra que estos residuos industriales son adsorbentes efectivos de iones plomo en soluciones acuosas en el rango de las concentraciones de trabajo utilizadas.
\end{abstract}

Palabras clave Cascarilla de laminación. Lodo de horno alto. Plomo. Adsorción. Isotermas de adsorción.

\section{INTRODUCTION}

The effluents generated by modern industries generally have a complex composition which includes metals (ions or complexes), suspended solids and other components ${ }^{[1]}$. According to increasingly stringent environmental laws, these effluents must be decontaminated because of their hazard to humans, animals and plants. Metals are non-biodegradable and can accumulate in living tissues, thus becoming concentrated throughout the food chain. High levels of lead in the blood in the infantile population are an important risk of mental slight delay and of increase of the arterial pressure.
Also they can provoke changes in the conduct, as irritability, hyperactivity and lack of attention. There can appear also other neurological disorders, anemia, renal problems and alterations in the growth and development.

Several technologies have been proposed for the removal of metals, such as precipitation, ion exchange, solvent extraction, adsorption, cementation on iron, membrane processing and electrolytic methods ${ }^{[2-8]}$. The use of different industry byproducts as adsorbent materials for the removal of metals from aqueous effluents has recently begun to be developed, with the aim of seeking alternative ways of recycling certain by-products and at the

(·) Trabajo recibido el día 26 de febrero de 2007 y aceptado en su froma final el día 29 de noviembre de 2007.

* Departamento de Ciencia e Ingeniería de Materiales e Ingeniería Química, Universidad Carlos III de Madrid, Avda. de la Universidad, 30, 28911 Leganés, Madrid, España.

** Departamento de Metalurgia Primaria y Reciclado de Materiales, Centro Nacional de Investigaciones Metalúrgicas (CENIM), Avda. Gregorio del Amo, 8, 28040 Madrid, España. 
same time finding cheaper replacements for expensive conventional sorbent materials in different situations ${ }^{[2,9-12]}$. In previous studies we have investigated the possibility of using a steelmaking industry by-product -rolling mill scalein the removal of copper ions from aqueous solutions ${ }^{[4]}$.

In the present work we have investigated the capacity of rolling mill scale and blast furnace sludge to remove $\mathrm{Pb}^{2+}$ ions, which may be present in liquid effluents.

Rolling mill scale is a steelmaking by-product from hot rolling processes which contains variable amounts of oil and grease. Spain generates about $44,000 \mathrm{t}$ of mill scale every year ${ }^{[13]}$. The oil component in rolling mill scale makes its recycling difficult, and its direct reuse in sintering may lead to environmental pollution problems. Mill scale with a high oil content is recycled after extracting the oil in a pretreatment stage or is dumped. Coarse scale with a particle size of $0.5-5 \mathrm{~mm}$ and an oil content of less than $1 \%$ can be returned to the sinter strand without any pretreatment ${ }^{[13]}$.

Blast furnace sludge is another by-product of the steelmaking industry. Gases generated during the manufacturing of pig iron are cleaned prior to their emission into the atmosphere using any of several systems. When a wet process is used the effluent consists of a sludge, which is led to a Dorr thickener to increase its concentration. This study considers the concentrated sludge obtained from such a thickener. About 31,000 t of blast furnace sludge is produced in Spain every year ${ }^{[14]}$.

\section{MATERIALS AND METHODS}

The mill scale used in this work was supplied from a hot rolling mill in an electric steelshop in northern Spain. It was dried at $80^{\circ} \mathrm{C}$ for $24 \mathrm{~h}$, revealing an initial moisture content of $5 \%$. For its chemical analysis the mill scale was crushed to obtain a grain size of $<40 \mathrm{~mm}$. The chemical composition of the ground sample was determined by wavelength dispersion X-ray fluorescence analysis (WDXRF) using a Philips PW-1404 spectrometer. The analysis of metallic iron was performed by titrating with a $0.1 \mathrm{~N} \quad \mathrm{~K}_{2} \mathrm{Cr}_{2} \mathrm{O}_{7}$ solution with barium diphenylamine-sulfonate as indicator. For this determination the sample was first treated with a bromine-methanol solution, filtering of the residual oxides with a $20 \mathrm{~mm}$ crucible, with the $\mathrm{Fe}^{0}$ soluble in bromine-methanol passing into the filtrate ${ }^{[15]}$.

The original sludge, provided by a Spanish company, was a $57 \% \mathrm{w} / \mathrm{w}$ suspension of solids in water. The suspension was vacuum-filtered and the resulting solid was dried at $80^{\circ} \mathrm{C}$ for $24 \mathrm{~h}$ before being crushed to yield a powder of a particle size of less than $40 \mathrm{~mm}$. The chemical composition of the sample was determined by wavelength dispersion $\mathrm{X}$-ray fluorescence analysis (WDXRF) using a Philips PW-1404 spectrometer. Carbon and sulfur analyses in both cases were carried out by combustion in a Leco CS-244 oven and infrared detection.

The crystalline mineralogical composition of these by-products was determined by X-ray diffraction (XRD) using a Siemens D-5000 diffractometer $\left(\mathrm{Cu} \mathrm{K} \mathrm{K}_{\alpha}\right.$ radiation).

The $\mathrm{N}_{2}$ adsorption isotherm was determined at $77 \mathrm{~K}$ for samples previously degasified at $60^{\circ} \mathrm{C}$ and $10^{-5}$ torr for $120 \mathrm{~min}$, using a Coulter SA-3100 unit. The isotherm data was used to determine the BET specific area values of the materials studied. For the removal of lead experiments the mill scale previously dried at $80^{\circ} \mathrm{C}$ for $24 \mathrm{~h}$ was passed through a screen, using only the $<0.5 \mathrm{~mm}$ fraction in the tests ${ }^{[12]}$. $\mathrm{Pb}^{2+}$ solutions were prepared by dissolving $\mathrm{Pb}\left(\mathrm{NO}_{3}\right)_{2}$ (chemical of reagent grade) in $0.01 \mathrm{M} \mathrm{NaNO}_{3}$, in order to maintain a constant ionic strength of the dissolution. $100 \mathrm{ml}$ of the metal solution was added to $10 \mathrm{~g}$ of mill scale in Erlenmeyer flasks. Adsorption tests with the mill scale were performed using aqueous metallic solutions with concentrations varying between 0.015 and $3.0 \mathrm{~g} / \mathrm{l}$. On the other hand, $100 \mathrm{ml}$ of the metal solution was added to 5 $\mathrm{g}$ of sludge. Removal tests with the sludge were performed using aqueous solutions with concentrations varying between 0.015 and $10 \mathrm{~g} / \mathrm{l}$. The samples were kept in constant suspension by means of a thermostatically-controlled Lauda MS-20 unit at different temperatures (between 20 and $80^{\circ} \mathrm{C}$ ) for an equilibrium time of $5 \mathrm{~h}$. Tests were previously performed at different reaction times in order to determine the equilibrium time. The equilibrium $\mathrm{pH}$ was $\mathrm{pH}_{\text {eq }}=5.0 \pm 0.1$. The $\mathrm{pH}$ was controlled using a Crison $517 \mathrm{pH}$-meter. The resulting suspensions were filtered and the solutions analysed by atomic absorption spectrophotometry (AAS) with a Varian SpectrAA-220FS spectrophotometer. Reproducibility of the results was $\pm 2 \%$. All experimental work used deionized water. The adsorption tests were realized before with samples of the adsorbent materials and deionized water. The lead concentration in solution was determined being zero so much with mill scale as with sludge. The amount of metallic ion adsorbed on the mill scale and the sludge was determined by establishing the difference between the initial concentration and the equilibrium concentration. 


\section{RESULTS AND DISCUSSION}

\subsection{Characterisation of materials}

Rolling mill scale has a laminar morphology and low specific surface area $\left(\mathrm{S}_{\mathrm{BET}}=0.43 \mathrm{~m}^{2} / \mathrm{g}\right)$. It is composed mainly of a mixture of iron oxides: wustite $(\mathrm{FeO})$, hematite $\left(\alpha-\mathrm{Fe}_{2} \mathrm{O}_{3}\right)$ and magnetite $\left(\mathrm{Fe}_{3} \mathrm{O}_{4}\right)$, and metallic iron. Its iron content is $\mathrm{Fe}_{\text {total }}=68.20 \%$ $\left(\mathrm{Fe}^{0}=7.20 \%(<0.5 \mathrm{~mm}\right.$ fraction $\left.)\right)$. The chemical composition of the mill scale is shown in table I. Approximately $2 \%$ of mill scale is composed of oils and greases from the lubrication of the rolling machines.

Blast furnace sludge is a complex heterogeneous material with a specific surface area of $27.43 \mathrm{~m}^{2} / \mathrm{g}$. Its morphology shows heterogeneity in the shape and size of the different particles. The sludge is composed mainly of hematite $\left(\alpha-\mathrm{Fe}_{2} \mathrm{O}_{3}\right)$ and coke with minor quantities of wustite $(\mathrm{FeO})$, magnetite $\left(\mathrm{Fe}_{3} \mathrm{O}_{4}\right)$, maghemite $\left(\gamma-\mathrm{Fe}_{2} \mathrm{O}_{3}\right)$, calcium ferrite $\left(\mathrm{CaO} \cdot \mathrm{Fe}_{2} \mathrm{O}_{3}\right)$, quartz $\left(\mathrm{SiO}_{2}\right)$ and calcium and aluminium silicates. Its iron content is $\mathrm{Fe}_{\text {total }}=33.00 \%$. The chemical composition of the sludge is shown in table II.

Table I. Chemical composition of the rolling mill scale

Table I. Composición química de la cascarilla de laminación

\begin{tabular}{cc}
\hline Element & Weight (\%) \\
\hline $\mathrm{Fe}$ & 68.20 \\
$\mathrm{Mn}$ & 0.48 \\
$\mathrm{Cu}$ & 0.47 \\
$\mathrm{Si}$ & 0.25 \\
$\mathrm{Ca}$ & 0.13 \\
$\mathrm{Ni}$ & 0.11 \\
$\mathrm{Cr}$ & 0.07 \\
$\mathrm{Mg}$ & 0.05 \\
$\mathrm{Hf}$ & 0.04 \\
$\mathrm{Ho}$ & 0.04 \\
$\mathrm{Zn}$ & 0.03 \\
$\mathrm{Co}$ & 0.03 \\
$\mathrm{As}$ & 0.03 \\
$\mathrm{Ir}$ & 0.03 \\
$\mathrm{Sn}$ & 0.03 \\
$\mathrm{P}$ & 0.02 \\
$\mathrm{Ga}$ & 0.02 \\
$\mathrm{Pt}$ & 0.02 \\
$\mathrm{~S}_{\text {total }}$ & 0.04 \\
$\mathrm{C}_{\text {total }}$ & 0.21 \\
\hline
\end{tabular}

Table II. Chemical composition of the blast furnace sludge

Table II. Composición química del lodo de horno alto

\begin{tabular}{cc}
\hline Element & Weight (\%) \\
\hline $\mathrm{Fe}$ & 33.00 \\
$\mathrm{Si}$ & 3.65 \\
$\mathrm{Al}$ & 1.70 \\
$\mathrm{Ca}$ & 2.30 \\
$\mathrm{Mg}$ & 0.70 \\
$\mathrm{~K}$ & 0.18 \\
$\mathrm{Na}$ & 0.06 \\
$\mathrm{Zn}$ & 1.20 \\
$\mathrm{~Pb}$ & 0.75 \\
$\mathrm{~S}_{\text {total }}$ & 1.15 \\
$\mathrm{C}_{\text {total }}$ & 34.05 \\
\hline
\end{tabular}

\subsection{Adsorption experiments}

\subsubsection{Influence of temperature}

Figure 1 shows the relationship between the different quantities of $\mathrm{Pb}^{2+}$ ions removed (or adsorbed) per unit of mass of adsorbent material (mill scale or sludge) and the equilibrium concentration of the metal ion at different temperatures for a reaction time of $5 \mathrm{~h}$. The amount of $\mathrm{Pb}^{2+}$ removed per unit of mass of mill scale remains practically constant with temperature (Fig. $1 \mathrm{a}$ )). In figure $1 \mathrm{~b}$ ) is observed that all the sorption isotherms exhibit a similar shape. The adsorption capacity of sludge increases with temperature.

\subsubsection{Adsorption isotherms}

Analysis of the relationship between adsorbent materials adsorption capacity and metal cation concentration at equilibrium was performed using the equations of Langmuir:

$$
C / X=1 / X_{m} b+C / X_{m}
$$

where, $\mathrm{X}$ is the amount of metal ion adsorbed per unit of mass of mill scale or sludge, $\mathrm{X}_{\mathrm{m}}$ and a indicate the adsorption capacity of the adsorbent material, $\mathrm{b}$ and $\mathrm{n}$ are constants referring to adsorption intensity and $\mathrm{C}$ is the cation concentration at equilibrium.

The Langmuir isotherm is based on the assumptions that every adsorption site is equivalent 
POSSIBILITY OF USING BY-PRODUCTS OF THE STEELMAKING INDUSTRY FOR REMOVING LEAD FROM AQUEOUS SOLUTIONS POSIBILIDAD DE USAR SUBPRODUCTOS DE LA INDUSTRIA DEL ACERO PARA ELIMINAR PLOMO DE SOLUCIONES ACUOSAS
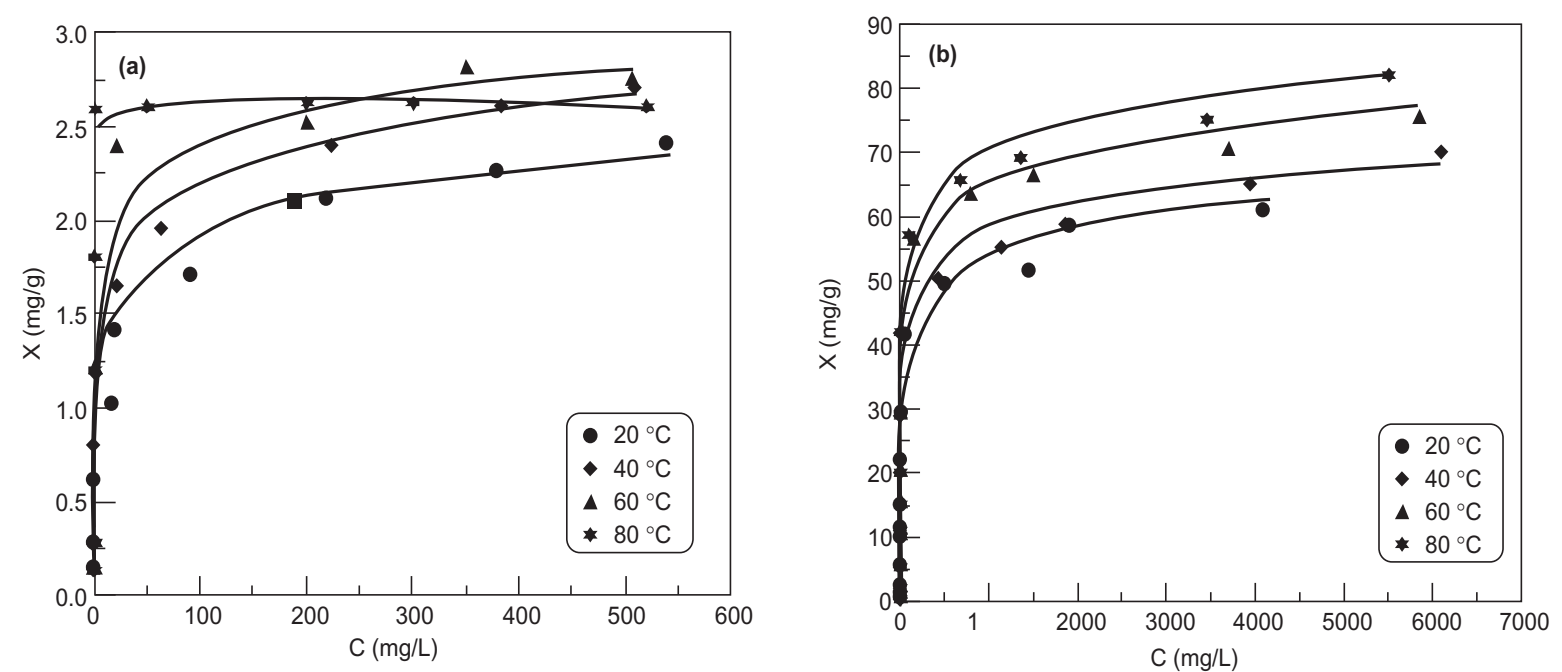

Figure 1. Mass of $\mathrm{Pb}^{2+}$ ions adsorbed per unit of mass of adsorbent material as a function of the cation equilibrium concentration in solution. $X=$ Amount of metal ion adsorbed per unit of mass of mill scale or sludge, $C=$ Cation concentration at equilibrium. Equilibrium time $=5 \mathrm{~h}$, (a) Mill scale, (b) Sludge.

Figura 1. Masa de iones $\mathrm{Pb}^{2+}$ adsorbidos por unidad de masa de material adsorbente en función de la concentración del catión en solución en el equilibrio. $X=$ Cantidad de ión metálico adsorbido por unidad de masa de cascarilla o lodo, $C$ = Concentración del catión en el equilibrio. Tiempo de equilibrio $=5$ h, (a) Cascarilla, (b) Lodo.

and that ability of a particle to bind there is independent of whether or not adjacent sites are occupied ${ }^{[16]}$.

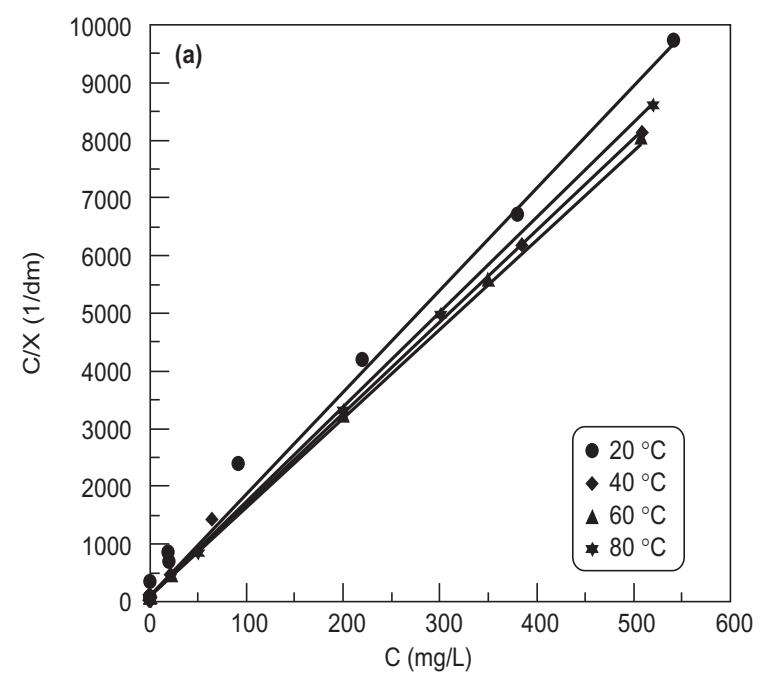

Figure 2 shows Langmuir isotherms for the adsorption of $\mathrm{Pb}^{2+}$ in aqueous solution on mill scale and/or sludge at different temperatures. The metal

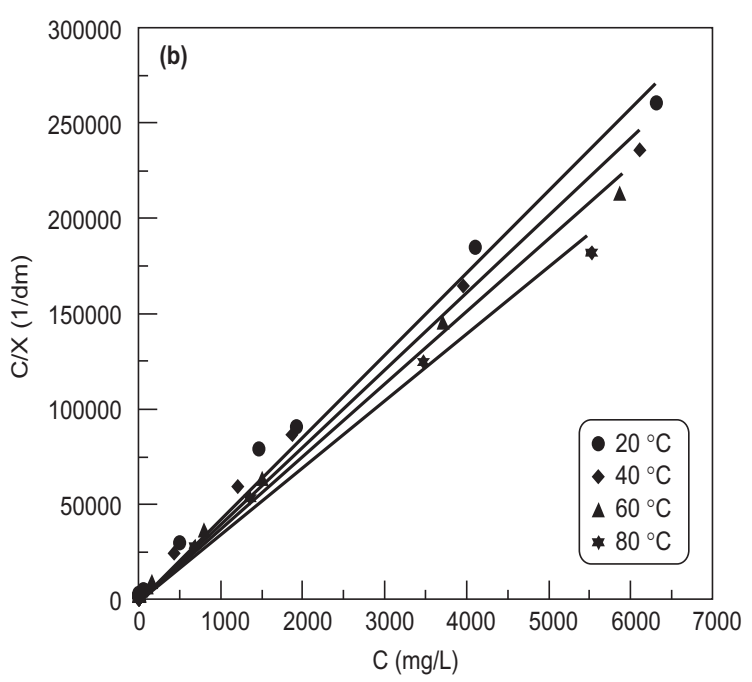

Figure 2. Langmuir isotherms. $X=$ Amount of metal ion adsorbed per unit of mass of mill scale or sludge, $C=$ Cation concentration at equilibrium. Equilibrium time $=5 \mathrm{~h}$, mill scale concentration $=100$ $\mathrm{g} / \mathrm{l}$ and sludge concentration $=50 \mathrm{~g} / \mathrm{l}$, (a) Mill scale, (b) Sludge.

Figura 2. Isotermas de Langmuir. $X=$ Cantidad de ión metálico adsorbido por unidad de masa de cascarilla o lodo, $C=$ Concentración del catión en el equilibrio. Tiempo de equilibrio $=5 \mathrm{~h}$, concentración de cascarilla = $100 \mathrm{~g} / \mathrm{l}$ y concentración de lodo = $50 \mathrm{~g} / \mathrm{l}$, (a) Cascarilla, (b) Lodo. 
solution concentration was varied and the reaction time was fixed at $5 \mathrm{~h}$. The Langmuir values $\mathrm{X}_{\mathrm{m}}$ and $\mathrm{b}$ were calculated respectively as the slope and the $\mathrm{C} / \mathrm{X}$ intercept of each isotherm line at different temperatures and are shown in table III. The experimental results fit the Langmuir model well for both studied materials $\left(\mathrm{R}^{2} \geqslant 0.994\right.$ - mill scale and $\mathrm{R}^{2} \geqslant 0.990$ - sludge).

In table III is observed also that the adsorption of $\mathrm{Pb}^{2+}$ on mill scale is practically independent of temperature and the adsorption capacity of this adsorbent material is very low $\left(\mathrm{X}_{\mathrm{m}}=2.74 \mathrm{mg} / \mathrm{g}-\mathrm{T}=60^{\circ} \mathrm{C}\right)$ (Fig. $3 \mathrm{a})$ ); but the adsorption of metal on sludge is dependent of temperature (Fig. 3 b)). The adsorption capacity of sludge rises with the increase of temperature.

\subsubsection{Thermodynamic values}

The values for the apparent equilibrium constant $\left(\mathrm{K}_{\mathrm{c}}\right)$ of the adsorption process of lead in aqueous solution on by-products of the steelmaking industry were calculated with respect to temperature ${ }^{[17]}$ at different initial concentration values and constant mill scale or sludge concentration $(100 \mathrm{~g} / \mathrm{l}-$ mill scale and $50 \mathrm{~g} / \mathrm{l}$ - sludge $)$ and residence time $(5 \mathrm{~h})$ :

Table III. Langmuir parameters as a function of temperature. Rolling mill scale concentration $=100$ $\mathrm{g} / \mathrm{l}$, blast furnace sludge concentration $=50 \mathrm{~g} / \mathrm{l}$

Tabla III. Parámetros de Langmuir en función de la temperatura. Concentración de la cascarilla de laminación $=100 \mathrm{~g} / \mathrm{l}$, concentración del lodo de horno alto $=50 \mathrm{~g} / \mathrm{l}$

\begin{tabular}{cccccccc}
\hline \multicolumn{3}{c}{ Rolling mill scale } & \multicolumn{5}{c}{ Blast furnace sludge } \\
\hline Ion & $\mathrm{T}\left({ }^{\circ} \mathrm{C}\right)$ & $\mathbf{X}_{\mathrm{m}}(\mathrm{mg} / \mathrm{g})$ & $\mathbf{b}(\mathrm{I} / \mathrm{mg})$ & $\mathrm{R}^{2}$ & $\mathbf{X}_{\mathrm{m}}(\mathrm{mg} / \mathrm{g})$ & $\mathbf{b}(\mathbf{l} / \mathbf{m g})$ & $\mathrm{R}^{2}$ \\
\hline $\mathrm{Pb}^{2+}$ & 20 & 2.45 & 0.062 & 0.994 & 64.17 & 0.017 & 0.990 \\
$\mathrm{~Pb}^{2+}$ & 40 & 2.72 & 0.145 & 0.998 & 68.23 & 0.018 & 0.991 \\
$\mathrm{~Pb}^{2+}$ & 60 & 2.74 & 0.751 & 1 & 73.65 & 0.030 & 0.990 \\
$\mathrm{~Pb}^{2+}$ & 80 & 2.60 & 2.005 & 1 & 79.87 & 0.033 & 0.990 \\
\hline
\end{tabular}
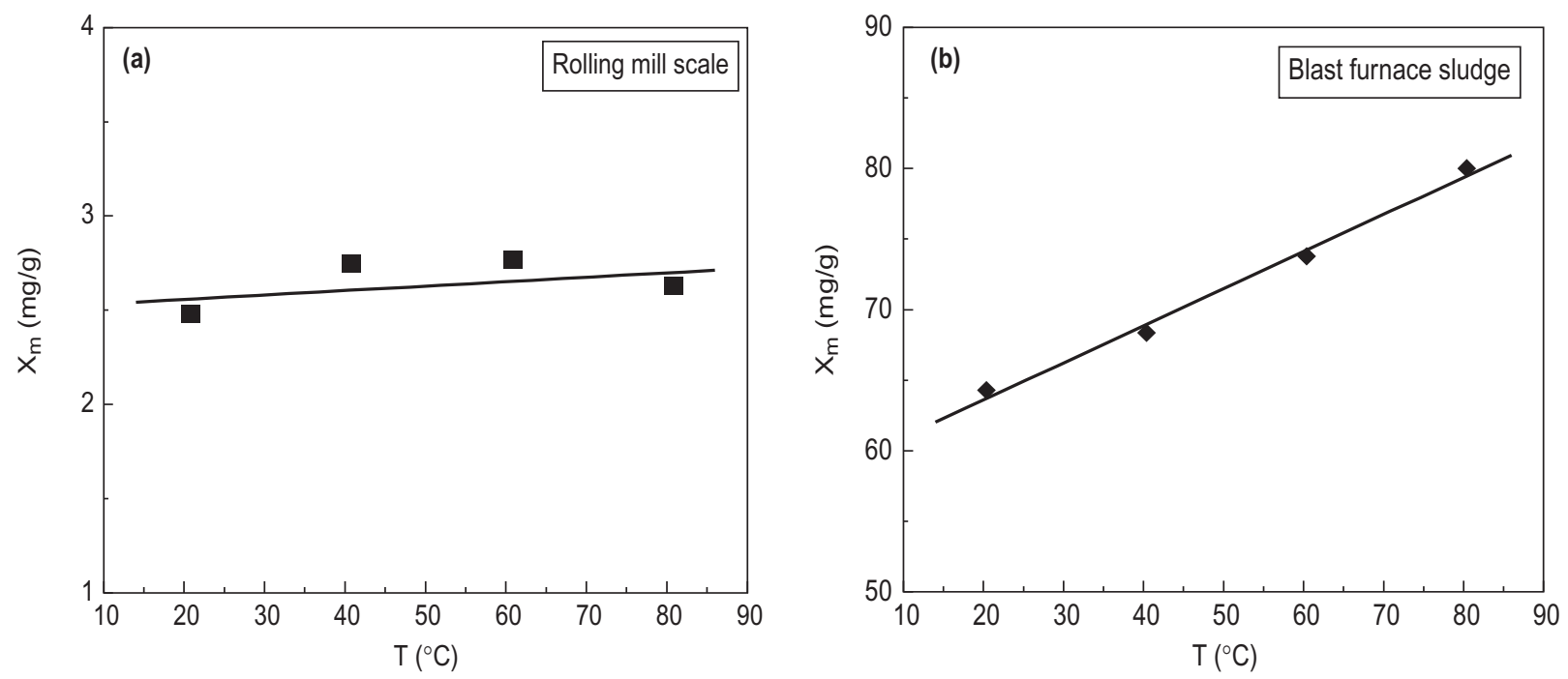

Figure 3. Variation of $X_{m}$ with temperature. $X_{m}$ indicate the adsorption capacity of the adsorbent material. Equilibrium time $=5 \mathrm{~h}$, mill scale concentration $=100 \mathrm{~g} / \mathrm{l}$ and sludge concentration $=50 \mathrm{~g} / \mathrm{l}$, (a) Mill scale, (b) Sludge.

Figura 3. Variación de $X_{m}$ con la temperatura. $X_{m}$ indica la capacidad de adsorción del material adsorbente. Tiempo de equilibrio $=5 \mathrm{~h}$, concentración de cascarilla $=100 \mathrm{~g} / \mathrm{l}$ y concentración de lodo $=$ $50 \mathrm{~g} / \mathrm{l}$, (a) Cascarilla, (b) Lodo. 
POSSIBILITY OF USING BY-PRODUCTS OF THE STEELMAKING INDUSTRY FOR REMOVING LEAD FROM AQUEOUS SOLUTIONS POSIBILIDAD DE USAR SUBPRODUCTOS DE LA INDUSTRIA DEL ACERO PARA ELIMINAR PLOMO DE SOLUCIONES ACUOSAS

$$
\mathrm{K}_{\mathrm{c}}=\% \text { adsorción } / 100-\% \text { adsorción }
$$

Table IV also shows the thermodynamic values $\Delta \mathrm{G}^{\circ}, \Delta \mathrm{H}^{\circ}$ and $\Delta \mathrm{S}^{\circ}$ for the adsorption processes of lead. In the case of the mill scale, the $\mathrm{K}_{\mathrm{c}}$ values are practically independent of temperature. $K_{c}$ values increased with temperature in the case of the $\mathrm{Pb}$ adsorption process on sludge. These values were calculated from the $\mathrm{K}_{\mathrm{c}}$ values using equation 3 and equation 4:

$$
\begin{gathered}
\Delta \mathrm{G}^{\circ}=-\mathrm{RT} \ln \mathrm{K}_{\mathrm{c}} \\
\ln \mathrm{K}_{\mathrm{c}}=\Delta \mathrm{H}^{\circ} / \mathrm{RT}+\Delta \mathrm{S} / \mathrm{R}
\end{gathered}
$$

The $\Delta \mathrm{G}^{\circ}$ values (negative $\Delta \mathrm{G}^{\circ}$ values, consistent with spontaneous reactions) of $\mathrm{Pb}$ decreased with temperature in the case of adsorption process on sludge. $\Delta \mathrm{H}^{\circ}$ values were positive, consequently the adsorption of $\mathrm{Pb}^{2+}$ on sludge and mill scale may be considered an endothermic process. This result is in agreement with the variation of $\mathrm{X}_{\mathrm{m}}$ with temperature shown in table III. Values for $\Delta S^{\circ}$ were positive and didn't show significant variation with temperature.

\subsection{Desorption experiments}

The resultant products of the adsorption process are products loaded with heavy metals and these residues cannot be incorporated into the sinter feed for recycling due to the fact that these might accumulate

Table IV. Thermodynamic values of the adsorption processes

\begin{tabular}{|c|c|c|c|c|c|c|}
\hline Ion & $\begin{array}{c}\mathrm{C}_{0} \\
(\mathrm{mg} / \mathrm{l})\end{array}$ & $\begin{array}{c}\mathrm{T} \\
\left({ }^{\circ} \mathrm{C}\right)\end{array}$ & $\ln \mathrm{K}_{\mathrm{c}}$ & $\begin{array}{c}\Delta \mathrm{G}^{\circ} \\
(\mathrm{kJ} / \\
\mathrm{mol})\end{array}$ & $\begin{array}{c}\Delta \mathrm{H}^{\circ} \\
(\mathrm{kJ} / \\
\mathrm{mol})\end{array}$ & $\begin{array}{c}\Delta \mathrm{S}^{\circ} \\
(\mathrm{kJ} / \\
\mathrm{K} \mathrm{mol})\end{array}$ \\
\hline
\end{tabular}

\section{Tabla IV. Valores termodinámicos de los procesos de adsorción}

Rolling mill scale
$\begin{array}{lllllll}\mathrm{Pb}^{2+} & 780 & 20 & -0.8 & - & - & - \\ \mathrm{Pb}^{2+} & 780 & 40 & -0.6 & - & - & - \\ \mathrm{Pb}^{2+} & 780 & 80 & -0.7 & - & - & -\end{array}$

Blast furnace sludge

\begin{tabular}{llllrl}
\hline $\mathrm{Pb}^{2+}$ & 2950 & 20 & 1.59 & -3.8828 .26 & 0.11 \\
$\mathrm{~Pb}^{2+}$ & 2950 & 40 & 1.74 & -4.5328 .26 & 0.11 \\
$\mathrm{~Pb}^{2+}$ & 2950 & 80 & 3.41 & -10.0128 .26 & 0.11
\end{tabular}

on the wall of the blast furnace and damage the refractories.

Previous experiments ${ }^{[15]}$ have shown that desorption of $\mathrm{Pb}^{2+}$ from these loaded steelmaking industry by-products, cannot be achieved using water and can be achieved with $\mathrm{HCl} 1 \mathrm{M}$, but chemical attack by diluted mineral acids ( $\mathrm{HCl} 1 \mathrm{M})$ also promoted the dissolution of the by-product.

Thus the stability of the loaded mill scale was studied for various times to assess the possibility of dumping the material in a landfill. In the experiment performed for a short time "leaching analysis" ${ }^{[17]}$ mill scale loaded with $\mathrm{Pb}^{2+}(0.07 \mathrm{mg} / \mathrm{g})$ was used and 200 $\mathrm{ml}$ of distilled water was added to $12.5 \mathrm{~g}$ of the loaded mill scale in an Erlenmeyer flask. The samples were kept in constant suspension at $\mathrm{pH}=5.00 \pm 0.01$ (adjuste with acetic acid $0.5 \mathrm{~mol} / \mathrm{l}$ ) for $24 \mathrm{~h}$. The results of the leaching analysis shows that the concentration of $\mathrm{Pb}\left([\mathrm{Pb}]_{\text {leached }}=0.3 \mathrm{~m} / \mathrm{g}, \mathrm{Pb}\right.$ leached $\left.=9.7 \%\right)$ is less than the EPA limit ${ }^{[18]}\left([\mathrm{Pb}]_{\text {leached }}=5.0 \mathrm{~m} / \mathrm{g}\right)$.

"Long times ${ }^{[15]}$ stability experiment" was carried out over 135 days at $20^{\circ} \mathrm{C}$. Mill scales loaded with $\mathrm{Pb}^{2+}(1.00 \mathrm{mg} / \mathrm{g})$ were used with $120 \mathrm{ml}$ of distilled water added to $0.5 \mathrm{~g}$ of loaded mill scale in Erlenmeyer flasks. The test was carried out at $\mathrm{pH}=5.00 \pm 0.01$ and $\mathrm{pH}=3.00 \pm 0.01$ (adjusted with sulfuric acid $50 \% \mathrm{v} / \mathrm{v})$. The results show $\left([\mathrm{Pb}]_{\mathrm{pH}}=5.00=0\right.$ and $\left.[\mathrm{Pb}]_{\mathrm{pH}=3.00}=0.6 \mathrm{mg} / \mathrm{l}\right)$ that at $\mathrm{pH} 5.00\left[\mathrm{~Pb}^{2+}\right]$ under the experimental conditions studied is smaller than the limit defined by the Spanish Law 29/1985 [19] (legal limit $=(0.5-0.2) \mathrm{mg} / \mathrm{l})$. At $\mathrm{pH}=3.0$ both $\left[\mathrm{Pb}^{2+}\right]$ is above their limits under the experimental conditions studied.

Previous studies ${ }^{[9]}$ with loaded blast furnace sludge had proposed an alternative process to dumping because of its easily leached metal content. This process converts the loaded sludge into pellets using a disc pelletizer with a mixture of calcium carbonate, coke and bentonite ${ }^{[10]}$. The pellets obtained are then mixed with $\mathrm{SiO}_{2}$ and heated to about $1,000^{\circ} \mathrm{C}$ in a controlled atmosphere in an electric furnace to release molten iron and the loaded metal together with a slag. The iron, with a purity of approximately 95-96 wt \%, may be recycled in the steelmaking process $^{[9]}$. This method avoids the dumping of a sludge which, because of its easily leached metal content, is a toxic and hazardous waste.

\section{CONCLUSIONS}

The present investigation evaluates the use of two steelmaking industry by-products (rolling mill scale and blast furnace sludge) as adsorbents for the elimination of lead ions from aqueous solutions. 
The removal of lead occurs through an adsorption process of lead ions on the surface of steelmaking industry material. The experimental results were well fitted, in each case, with the Langmuir isotherms.

The adsorption processes of lead ions on sludge depend on the temperature, with the amount of removed (adsorbed) ions increasing as the temperature rises. The adsorption of the $\mathrm{Pb}^{2+}$ on blast furnace sludge can be considered an endothermic process. In the case of adsorption process of lead ions on millscale its adsorption is not dependent on the temperature.

The data obtained shows that rolling mill scale and blast furnace sludge are effective sorbents of $\mathrm{Pb}^{2+}$ and perform well over a wide range of concentrations.

The results indicate that the blast furnace sludge, that has a higher specific surface has a greater affinity for the metals than the rolling mill scale, that has a lower specific surface, at all the temperatures studied.

The treated by-products cannot be recycled in the steelmaking process because of their metal content. So these loaded by-products must either be treated to desorb the metals or dumped in a controlled landfill.

The utilisation of the sludge and the mill scale as metallic ions sorbents provides a potential use for these industrial waste products.

\section{REFERENCES}

[1] A. Kabata-Pendias and H. Pendias, 2001. Trace elements in soils and plants, CRC Press Inc., Florida.

[2] L. Curkovic, S. Cerjan-Stefanovic And A. RAstovèAn-Mió́, Water Res. 35(14) (2001) 3436-3440.

[3] P.D. JOHNSON, M.A. WATSON, J. BROWN AND I.A. JEFCOAT, Waste Manage 2 (2002) 471-480.

[4] F.A. LÓPEZ, M.I. MARTÍN, C. PÉREZ, A. LÓPEZDelgado AND F.J. AlguaCIL Water Res. 37 (2003) 3883-3890.
[5] M.I. MARTín, F.A. LÓPEZ, C. PÉREZ, A. LÓPEZDelgado and FJ. Alguacil, J. Chem. Technol. Biot. 80 (2005) 1223-1229.

[6] F.A. LÓPEZ, C. PÉREZ, E. SAINZ AND M. AlONSO, J. Chem. Technol.Biot. 62 (1995) 200-206.

[7] F.J. Alguacil, Rev. Metal. Madrid 39 (2003) 205-209.

[8] F. PÉrez-Moreno, F. Prieto-García, A. RoJAS-HERNÁNDEZ, Y. MARMOLEJO-SANTILLÁN, E. SALINAS-RODRÍGUEZ AND F. PATIÑO-CARDONA, Rev. Metal. Madrid 42 (2006) 391-395.

[9] E. Romera, F. GONZÁlez, A. BALlester, M.L. BlÁzQUez And J.A. MuÑoz, Rev. Metal. Madrid 43 (2007) 29-41.

[10] F.A. LÓPEZ, F. MEDINA, J. MEDINA AND M.A. PALACIOS, Ironmaking Steelmaking 18 (1998) 292-295.

[11] P. AsHODAN, M. SAXENA AND S.R. AsOlEKAR, Resour. Conserv. Recy. 43 (2005) 239-262.

[12] S. KUMAR, R. KUMAR AND A. BANDOPADHYAY, Resour. Conserv.Recy. 48 (2006) 301-314.

[13] IISI, The Management of Steel Plant Ferruginous By-Products, Committee on Environmental Affairs and Committee on Technology (Eds.), 1994, Brussels.

[14] A. LÓPEZ-DELGADO, C. PÉREZ AND F.A. LÓPEZ, Water Res. 32 (1998) 989-996.

[15] M.I. MARTín, Tesis Doctoral, Facultad de Ciencias Químicas, Universidad Complutense de Madrid, 2004.

[16] M. DíAz-PeÑA And A. Roig-Muntaner, Química Física, vol. 2, Ed. Alhambra Universidad, Madrid, España (1988), pp. 1034-1041.

[17] A. LóPEZ-DELGADO, C. PÉREZ AND F.A. LÓPEZ, Carbon 34 (1996) 423- 426.

[18] Federal Register, 1986. Toxicity Characteristics Leaching Procedure (TCLP), 51(216), Friday, November 7, USA, 40643-40654.

[19] Spanish LAW 29/1985, 2 August 1985, Real Decreto 849/1986, 11 April 1986, BOE 103, 30 April, 1986. http://www.gestion-ambiental.com/norma/ley/REAL_DECRETO_849-1986.htm. 